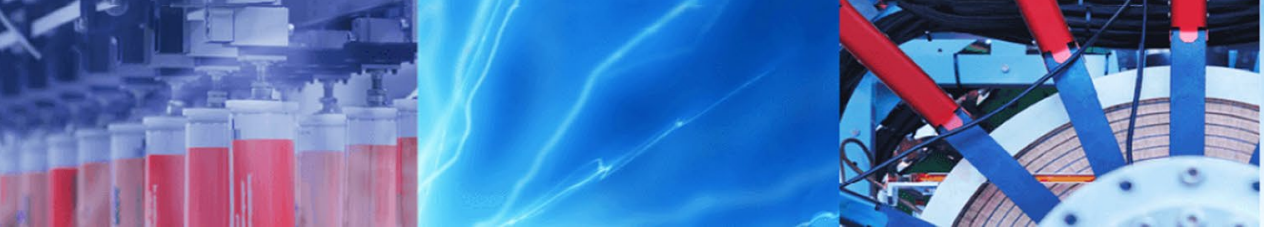

Research Article

\title{
The effect of exclosures on restoration of soil properties in Ethiopian lowland conditions
}

\author{
Kiros Abay $^{1} \cdot$ Sarah Tewolde-Berhan $^{2} \cdot$ Kassa Teka $^{3}$
}

Received: 28 April 2020 / Accepted: 17 September 2020 / Published online: 6 October 2020

(c) Springer Nature Switzerland AG 2020

\begin{abstract}
Land degradation is one of the environmental challenges in the semi-arid areas of Africa such as Ethiopia. To tackle this problem, exclosures have been established on degraded open grazing lands. However, there was paucity of research regarding their ecological merits, especially in the lowlands of Tigray, Northern Ethiopia. Hence, this study was conducted to explore the effect of conversion of grazing lands to an exclosure on soil chemical properties and soil organic carbon stock (SOC stock) in Tselemti district, which was taken as testing site to represent the lowlands of Tigray. A total of 36 plots ( 18 from grazing land and 18 from exclosure), measuring $20 \mathrm{~m} \times 20 \mathrm{~m}$, were established along 6 transects for soil sampling. From each plot, 1 composite soil sample for analyses of total nitrogen (TN), available phosphorus (avP), cation exchange capacity (CEC), electrical conductivity (EC), available potassium (avK), soil pH and soil organic carbon content (SOC) and 1 undisturbed soil sample for soil bulk density (BD) determination was collected from a depth of 0-30 cm. Hence, a total of 72 soil samples ( 36 for nutrients and 36 for bulk density analysis) were analyzed in the laboratory. Paired samples $t$ test statistics at $5 \%$ level of significance using SPSS version 20 was used to compare the land uses. Pearson correlation test was also used to analyze the relationship among the different soil properties. The study showed that the conversion of open grazing land to an exclosure enhanced most of the soil properties except soil $\mathrm{pH}$, avP and EC. The results revealed that the exclosure had significantly $(p<0.05)$ higher SOC $(1.89 \pm 0.1$ and $1.29 \pm 0.06)$ and SOC stock $\left(73.61 \pm 4.9\right.$ and $\left.45.64 \pm 2.57 \mathrm{Mg} \mathrm{ha}^{-1}\right)$, indicating an improvement by 46.5 and $61.3 \%$ as compared to the grazing land. Similarly, it enhanced CEC, TN and avK level significantly $(p<0.05)$ by $16.8,45.5$ and $34 \%$, respectively. It can be concluded that conversion of open grazing lands to exclosures is a viable option to restore degraded soils. For this reason, additional exclosures have to be established on previously degraded open grazing lands in the area and areas with similar biophysical setup.
\end{abstract}

Keywords Lowlands · Nutrients · Restoration · Soil organic carbon stock

$\begin{array}{ll}\text { Abbreviations } \\ \text { TN } & \text { Total nitrogen } \\ \text { avP } & \text { Available phosphorus } \\ \text { CEC } & \text { Cation exchange capacity } \\ \text { EC } & \text { Electrical conductivity } \\ \text { avK } & \text { Available potassium } \\ \text { SOC } & \text { Soil organic carbon content } \\ \text { BD } & \text { Bulk density }\end{array}$

\section{Abbreviations}

TN Total nitrogen

avP Available phosphorus

CEC Cation exchange capacity

EC Electrical conductivity

SOC Soil organic carbon content

BD Bulk density

\section{Introduction}

Land degradation, soil erosion and deforestation are serious problems in Ethiopia [1]. The country loses about 1493 million tons of top soil annually [2]. On the other hand, FAO [3] reported an estimated deforestation rate of $140,000-200,000$ ha per annum and as a consequence, the forest cover declined from 15.1 million ha in 1990 to 12.2

\footnotetext{
$\triangle$ Kiros Abay, kirosabay01@gmail.com | ${ }^{1}$ Shire-Maitsebri Agricultural Research Center, Tigray Agricultural Research Institute, Shire Endaselassie, Ethiopia. ${ }^{2}$ Department of Food Science and Post-Harvest Technology, Mekelle University, Mekelle, Ethiopia. ${ }^{3}$ Department of Land Resources Management and Environmental Protection, Mekelle University, Mekelle, Ethiopia.
} 
million ha in 2010. Tigray, Northern Ethiopia, is one of the most environmentally degraded regions in Ethiopia, characterized by erratic rainfall, overgrazing, deforestation, soil erosion, soil moisture stress, loss of biodiversity and soil fertility decline [4].

To overcome these challenges, conversion of previously open grazing lands to exclosures was one, among many environmental rehabilitation efforts that have been promoted and implemented in the region in the last 30 and more years $[5,6]$. Exclosures are areas exempted from the interference of humans and domestic animals with the goal of reducing land degradation and promoting natural regeneration of plants of formerly degraded grazing lands.

Studies conducted by authors [6-12] have shown the positive role of conversion of grazing lands to exclosures on restoration of soils that were previously degraded in the region. However, most of these studies focused in the mid (1500-2300 $\mathrm{m}$ above sea level) and highlands ( $>2300 \mathrm{~m}$ above sea level) with limited focus to the lowlands ( $<1500 \mathrm{~m}$ above sea level) such as the study area, Tselemti district.

Traditionally, the lowlands of Tigray are based on extensive livestock production, with higher livestock population than the highlands, whereas the farmers in the highlands have been mainly focusing on crop production due to land scarcity. This might bring a difference in the grazing intensity and stocking rate between the highland and lowland areas of the region. According to Amiri et al. [13], soil properties can be influenced by different grazing intensities and pointed out that heavily grazed areas ( $>3$ sheep $\mathrm{ha}^{-1}$ ) negatively influenced soil properties than moderately grazed areas ( $>1$ sheep $\mathrm{ha}^{-1}$ ). Heavy grazing can negatively influence vegetation by destroying and/or disrupting the soil structure, enhancing organic matter oxidation, and resulting in the changes of soil properties storage than light grazing. Furthermore, as a result of their high livestock population, some farmers in the lowlands of Tigray, including the study area, are pessimistic towards exclosure and are complaining about the management system and its benefits. They are not sure that it is giving them more benefit than if it was used for livestock rearing, since they do not like to be deprived from environmental resources where it is a means of pursuing their livelihoods. Besides, according to Evans et al. [14], in drier and arid ecological regions, there might be trade-offs between managing lands for rehabilitation and animal production. The same is true in the lowlands of Tigray. In addition, accumulation of soil nutrients can vary between lowlands and highlands due to varying decomposition rates since it could affect the nutrients turnover and difference in plant productivity [15]. According to the authors, the effect of exclosure under different agro-ecologies varied significantly, and reported that plots located in lowland site contained higher amounts of soil nutrients than their upland counterparts at equal topographic position and similar treatment. These all imply that the effect of livestock exclusion can vary between lowland and highlands at similar management practices.

The effectiveness of restoration options can be affected by the differences in ecological and socio-economic conditions, political and historical contexts and level of management [16]. The effect of land use conversion on soil nutrients and soil organic carbon stock ( $\mathrm{SOC}$ stock) is variable and it depends on soil type, land use history, vegetation type, climate, topography and current land use and land cover [17, 18]. According to Mekuria et al. [19], the effectiveness of establishing exclosures to restore degraded open grazing lands varies across different localities due to heterogeneity of exclosure management, soil, climate and topography. Furthermore, studies on the effect of conversion of grazing lands to exclosures on soil chemical properties and soil carbon stock have not been consistent. For instance:

i. Mekuria et al. [7, 20] and Yimer et al. [21] reported an increase in SOC stock and SOC, while the soil parameters were not significantly influenced by establishing exclosures [22].

ii. Tiki et al. [23] and Gebreanenia [24] reported an enhancement in TN level, whereas Munie [16] and Mekuria et al. [22] demonstrated a decrease and Yimer et al. [21] indicated a non-significant result.

iii. Bahiru [25] and Mekuria [26] indicated an increase in avP level, while Legesse [27], Mekuria et al. [22] reported a decrease. Asmamaw [28] also report a non- significant result.

iv. Tadesse [29] reported an increase in avK level, whereas Mekuria et al. [22] and Asmamaw [28] demonstrated higher in communal grazing land than in exclosures and a non-significant effect, respectively.

v. Mekuria et al. [30] pointed out an enhancement in CEC level, while Abiyu et al. [31] and Mekuria et al. [22] reported an insignificant result.

These results imply a lack of clear relationship between grazing exclusion and soil nutrients, which may result from the contributions of different climate, soil type, landscape position, management practices [32], years of grazing exclusion [33], and grassland ecosystem types [34].

For this reason, generalization is difficult unless several and representative studies are conducted across different locations in the region, since the agro-ecologies and climatic conditions varies highly in the region. This 
together with the inconclusiveness of the evidence indicates that there is a need to study the changes in soil properties and soil carbon stock following the establishment of exclosures. Therefore, studies which investigate the role of conversion of previously degraded grazing lands to exclosures under different agro-ecologies, socio-economic conditions, soil types and level of management are crucial. Moreover, quantifying the effect of establishing exclosures for ecological restoration is critical to provide important source of information for policy makers and planners to make informed decisions on the future fates of exclosures and for understanding the appropriate management and conservation of degraded communal grazing lands, designing ways of improving soil properties and soil carbon stock through exclosure establishment and create better awareness to the community to enhance their effort of land rehabilitation. Hence, this study was conducted to explore the effect of conversion of previously degraded communal grazing land into an exclosure on soil chemical properties and SOC stock in Tselemti district, Northern Ethiopia, representing the lowlands of Tigray region.

Based on the stated goals of restoration by exclosures, we hypothesize that exclosures can be effective in restoring degraded soil chemical properties and soil organic stock. Finally, the study will answer the research question "do exclosures established in lowland areas of Tigray region, Northern Ethiopia, have a potential to improve soil chemical properties and SOC stock?".

\section{Materials and methods}

\subsection{Study area}

The study was conducted at Mai-Saba exclosure and its adjacent grazing land, Sekota-Mariam Kebelle (the smallest political administration units in Ethiopia) in Tselemti district, Tigray, Northern Ethiopia (Fig. 1), which is $380 \mathrm{~km}$ far from Mekelle, capital city of Tigray region, towards North West. The district is located at $13^{\circ} 05^{\prime}$ latitude and $38^{\circ} 18^{\prime}$ longitude at an altitude of $1350 \mathrm{~m}$ above sea level (m a.s.l) [35]. Areas characterized at an elevation ranging from 500 to $1500 \mathrm{~m}$ a.s.l. are classified as lowland or locally called 'Kolla' [36]. The exclosure was protected (closed) against any disturbance from humans and livestock since 1999.

Five years (2012-2016) temperature data show that the temperature in the study area varies from $15.6^{\circ} \mathrm{C}$ in January to $38.6^{\circ} \mathrm{C}$ in April. The dry season occurs between November and April, while the rainy season occurs between June and September (Fig. 2). The study sites are characterized by rugged topography where the land is undulating with mountainous terrain and flat plains.

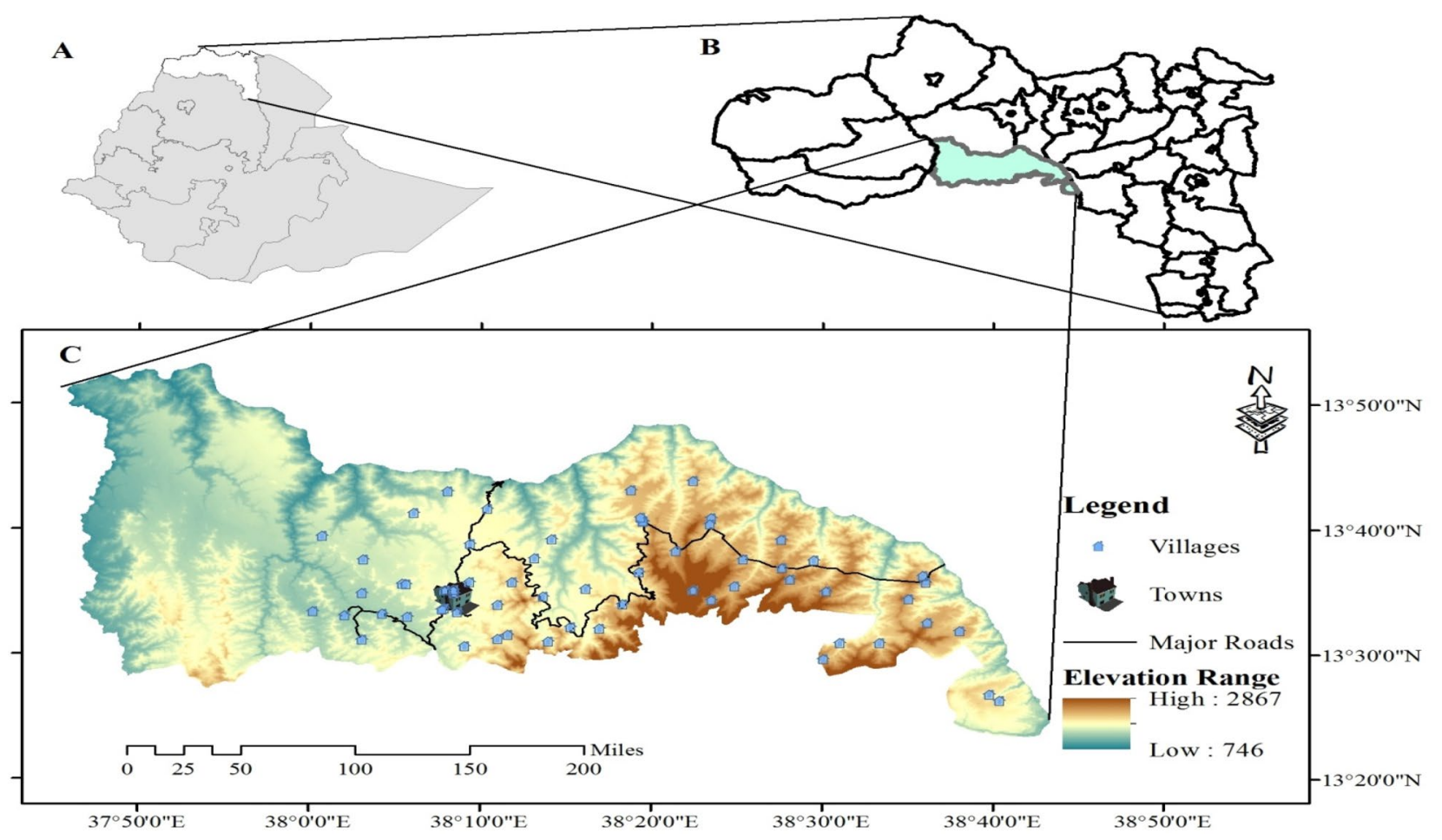

Fig. 1 Map showing the location of the study area. Town = Maitsebri town 


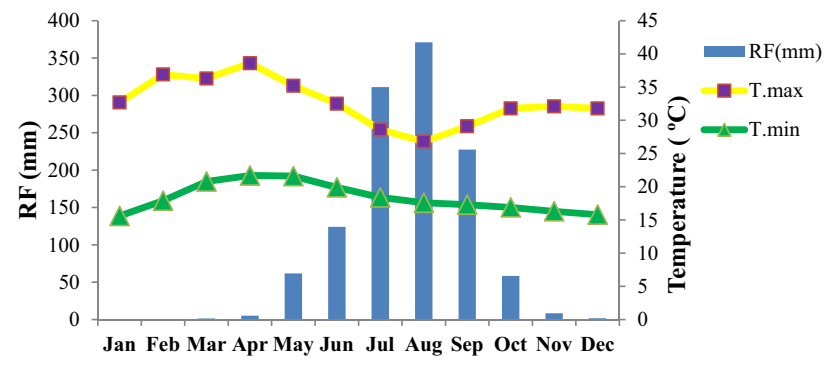

Fig. 2 Five years (2012-2016) mean monthly rainfall $(\mathrm{mm})$ and maximum and minimum mean monthly temperatures of the study area. Source: Tigray meteorological services center

A range of soil types are found in the district, but the dominant soil type on the escarpment slopes where this study was carried out are Cambisols [37]. These soils are soils which are at the beginnings of horizon differentiation in the subsoil evident from changes in structure and color, characterized by slight or moderate weathering of parent material and brownish discoloration as well [38]. The soil texture of these soils is loamy to clayey and the texture of the subsurface horizons are sandy loam or finer.Ziziphus spina-christi, Balanites aegyptiaca, Stereospermum kunthianum and Acacia abyssinica are the most common woody vegetation species in the exclosure and Anogeisus leiocarpus was the most dominant species in the grazing land. Of these species, Ziziphus spina-christi, Balanites aegyptiaca and Acacia abyssinica are nitrogen fixers. The community mainly depends on mixed agriculture (both crop and animal husbandry) for livelihood. The dominant crops grown are Sorghum bicolour L., Zea mays L. and Eleusine coracana L. [35] and the major livestock are donkeys, cattle, chicken and goats.

\subsection{Description and land management history of both the land uses}

Exclosures in the study area refer to areas exempted from the interference of humans and domestic animals with the goal of environmental rehabilitation, which are implemented on community land, most frequently on very steep and degraded slopes using community regulation by appointing guards. The exclosures are totally protected from any livestock and human activities until the community and local administration agree on its full rehabilitation. When all parties agree that the land is rehabilitated, the community uses the accessible part of the exclosures to harvest dry herbs during the dry season for livestock feed using cut and carry system. Harvesting is operated when herbs are dry and grass harvesting (using a cut and carry system) is allowed and is conducted once a year, starting 4-5 years after exclosure establishment. However, tree cutting is also not allowed. The area in this study was identified and prioritized for establishing exclosures as a joint initiative of governmental institutions mainly of development agents of office of agriculture and rural development and local communities. Then, final decisions were taken at a general meeting of the community so that to make the protection effective. Bylaws were devised through participatory process. For instance, there is a penalty when agreed rules are broken, e.g., when people illegally graze livestock or cut trees at night or when guards were not around. The current management-related activities relate to only guarding and harvesting grass annually. The long-term plans of establishing exclosures are for environmental rehabilitation and economic benefit. Once the exclosures are established, they will not be re-used for grazing.

Open grazing land represents the communal lands that are not privately owned, yet belonging to the communities whose members have equal access rights to the communal resources. On these lands, unlimited access for free grazing is practiced, while illegal tree cutting is not allowed. According to Mekuria et al. [7], the stocking rate of communal grazing lands is 1.4 livestock ha ${ }^{-1}$ year $^{-1}$. The area of the exclosure and the grazing land in this study is 20.3 and 28.8 ha, respectively. Accordingly, a total of 40.3 livestock could graze throughout the year. The communal grazing land was observed to be under heavy grazing pressure and severe land degradation. Rill and sheet erosion in the grazing land were observed to be relatively more common compared to the exclosure. In addition, it was characterized by low vegetation cover, sediment deposits and higher proportions of bare soil than the exclosure.

The exclosure in this study was protected (closed) against any disturbance from humans and livestock since 1999. Before establishment, the exclosure and the adjacent grazing land had similar conditions, because the exclosure was established on parts of the degraded communal grazing land that was used for livestock grazing which means the same site was divided into both exclosure and open grazing land and established in steep, eroded, and degraded areas that have been used for grazing in the past. Hence, it is assumed that the exclosure and the grazing lands were homogenous before the establishment of the exclosure. The distance between the exclosure and the adjacent grazing land was in the range of $50-100 \mathrm{~m}$. The elevation and slope gradient of the sampling plots in both the land uses range between 1196-1405 $\mathrm{m}$ and 7-44\%, respectively, with similar aspect (towards west) (Table 1 ). The abundant plant species were found to be naturally regenerated, while no planted seedlings were observed in both the land uses. Besides, no other management practices such as physical structures were observed.

\subsection{Experimental design and data collection}

Prior to this study, discussion with the local residents and experts from all administration levels, who have extensive 
Table 1 Characteristics of the sampling plots in both the studied land uses

\begin{tabular}{|c|c|c|c|c|c|c|}
\hline \multirow[t]{3}{*}{ Characteristics } & \multicolumn{6}{|l|}{ Land use } \\
\hline & \multicolumn{3}{|c|}{ Exclosure $(n=18)$} & \multicolumn{3}{|c|}{ Open grazing land $(n=18)$} \\
\hline & Minimum & Maximum & Mean \pm SEM & Minimum & Maximum & Mean \pm SEM \\
\hline Elevation (m.a.s.l) & 1196 & 1405 & $1298 \pm 19$ & 1201 & 1402 & $1300 \pm 18$ \\
\hline Slope (\%) & 8 & 40 & $23 \pm 2.9$ & 7 & 44 & $25 \pm 3$ \\
\hline Aspect & \multicolumn{3}{|l|}{ Towards west } & \multicolumn{3}{|l|}{ Towards west } \\
\hline Soil type & \multicolumn{3}{|l|}{ Cambisols } & \multicolumn{3}{|l|}{ Cambisols } \\
\hline Area of each plot & \multicolumn{3}{|l|}{$20 \mathrm{~m} \times 20 \mathrm{~m}$} & \multicolumn{3}{|l|}{$20 \mathrm{~m} \times 20 \mathrm{~m}$} \\
\hline
\end{tabular}

$n$ represents number of plots in each land use knowledge of study sites, was done. The experts and administrators were briefed on the study's objective to get permission since humans interference is not allowed in the closed area. Hence, they permit us to conduct the study in both the land uses. Visual field observations and a reconnaissance survey were conducted in the second week of November 2016 to collect the baseline information and determine the number of transect lines and plots to be laid.

Space for time substitution approach [39] was used to detect changes in soil chemical properties and SOC stock after conversion of grazing land to exclosure. According to Pickett [40], the approach has been a very widely used to the study of long-term phenomena in ecology and it has been used most often and most successfully, in systems acknowledged to have strong successional dynamics and has been long recognized as having potential for understanding community temporal dynamics. According to the author, it has been used to assess the impact of human-induced changes in the environment where preimpact records are sparse or nonexistent. Furthermore, this chronological method is widely adopted in applied ecosystem research [41], considered a "retrospective" research method, because it compares existing conditions with original conditions and treatments and it is an effective way of studying changes over time since disturbance or land use change in a region $[39,42,43]$. The implicit assumption of this approach is that exclosures and paired adjacent grazing lands had similar initial conditions such that the changes in soil properties after a time is a consequence of conversion process from open grazing lands to exclosures [20] and not by inherent site variability.

A systematic random sampling technique was used to collect soil samples. Three line transects parallel to each other and across the slope were laid in the exclosure and open grazing lands systematically at 150 meters interval. That is, we delineated three landscape positions (upper slope, mid-slope and foot slope) which were parallel to each other and to the topography of the landscape (Fig. 3).
The upper slope position is the upper most position of each land use and it receives little or no overland flow but may contribute runoff to down slope areas. The middle slope position receives overland flow from the upper slope and contributes runoff to the foot slope. The foot slope represents the lowest part of each study site and receives overland flow from both mid and upper slopes. Along each transect line, six sample plots measuring $20 \mathrm{~m} \times 20 \mathrm{~m}$ [44] were laid down at 100 meters intervals from each other. The first plot was laid down randomly in all of the transects and the other plots systematically at equal interval in each of the transects. To avoid the effect of disturbances, the first and the last line transects and plots were laid at a distance of at least $30 \mathrm{~m}$ from the edges from all sides in both of the land uses. From each plot, soil samples and all related information were collected from December to January 2016.

Thus, a total of 36 plots ( 18 plots from each land use type) were used to collect soil samples.

\subsection{Soil sampling}

In each of the 36 plots, five soil pits, from four corners and at the center, with an area of $1 \mathrm{~m} \times 0.6 \mathrm{~m}$, following the recommendation by Yimer et al. [21] were dug in an ' $X$ ' design in both the land uses. From each pit, soil samples from a depth of $0-30 \mathrm{~cm}$ [45] were collected and thoroughly mixed in a large bucket to form one composite soil sample per plot for TN, SOC, avK, avP, EC, CEC and soil pH analysis. According to Badgery et al. [46], effect of land use management changes are more likely to occur in the upper $0-30 \mathrm{~cm}$ profile. In one of the five pits, an undisturbed soil samples using core sampler of height $5 \mathrm{~cm}$ and diameter of $5 \mathrm{~cm}(5 \mathrm{~cm} \times 5 \mathrm{~cm})$ were also collected from each plot for BD determination. Hence, a total of 72 soil samples ( 36 for nutrients and 36 for BD analysis), from both land uses, were collected and submitted to Mekelle Soil Research Center laboratory, Tigray region. The collected composite soil samples 


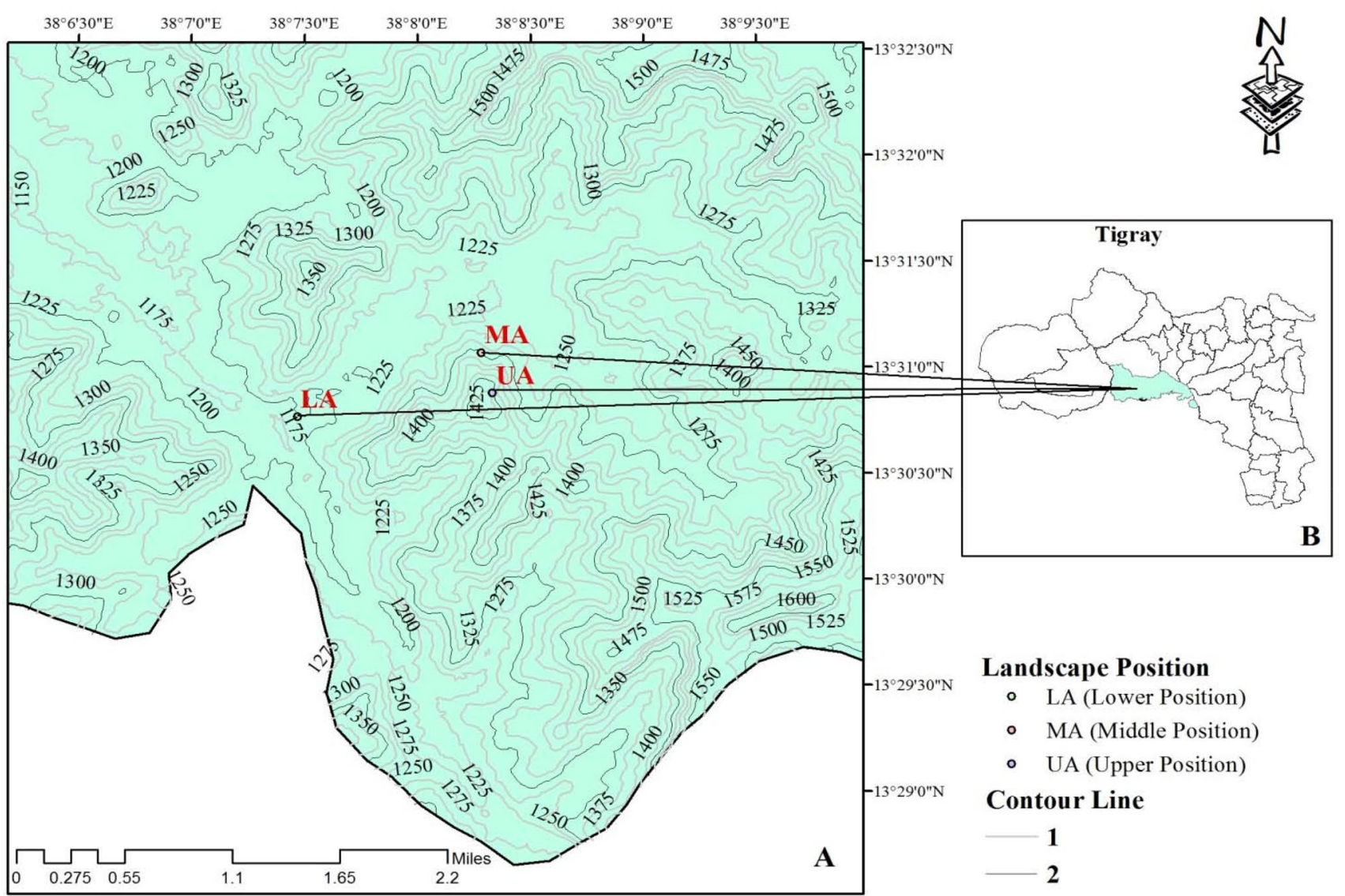

Fig. 3 Sampling across slope positions (a) and the study area (b). Each landscape position (LA, MA, UA) represents the position from which 12 sampling plots ( 6 from exclosure and 6 from grazing land) were taken

were air dried, grounded and passed through a $2 \mathrm{~mm}$ sieve prior to analysis.

\subsection{Soil laboratory analysis}

The collected soil samples were analyzed in laboratory using the methods given in Table 2 .

Table 2 Methods used to analyze the soil properties in laboratory

\begin{tabular}{lll}
\hline Soil property & Method used & References \\
\hline TN & Kjeldahl method & {$[47]$} \\
avP & Olsen-P method & {$[48]$} \\
SOC & Walkley-Black method & {$[49]$} \\
Soil pH & Water suspension method & {$[50]$} \\
avK & Flame photometry & {$[51]$} \\
EC & Sodium saturation ratio & {$[52]$} \\
CEC & Ammonium acetate method & {$[53]$} \\
BD & Core method & {$[54]$} \\
\hline
\end{tabular}

$\mathrm{TN}=$ Total nitrogen $(\mathrm{g} / 100 \mathrm{~g})$, avP $=$ Available phosphorus $\left(\mathrm{mg} \mathrm{kg}^{-1}\right)$, $\mathrm{SOC}=$ Soil organic carbon $(\mathrm{g} / 100 \mathrm{~g})$, avK=Available potassium $\left(\mathrm{mg} \mathrm{kg} \mathrm{kg}^{-1}\right), \mathrm{EC}=$ Electrical conductivity $\left(\mathrm{dS} \mathrm{m}^{-1}\right), \mathrm{CEC}=$ Cation exchange capacity $\left(\mathrm{cmol}(+) \mathrm{kg}^{-1}\right), \mathrm{BD}=$ Bulk density $\left(\mathrm{g} \mathrm{cm}^{-3}\right)$

\subsection{Soil organic carbon stock determination}

To determine the SOC stock, the dried, $2 \mathrm{~mm}$ sieved soil was weighed and the volume of coarse fragments was recorded for coarse fragments correction. Then, it was calculated using the following formula:

SOC stock $=\left[\mathrm{WBC} \times \mathrm{BD} \times \mathrm{D} \times\left(1-\frac{\mathrm{CF}}{100}\right)\right] \times 100$

where $W B C(\%)=$ Walkley-Black carbon content of the fine fraction $(<2 \mathrm{~mm}), D=$ soil depth $(\mathrm{cm}), \mathrm{BD}=$ soil bulk density $\left(\mathrm{g} \mathrm{cm}^{-3}\right) ; \mathrm{CF}=\%$ of volume of coarse fragments. The volumetric content of the coarse fragments ( $>2 \mathrm{~mm}$ material) was calculated from a density of rock fragments value of $2.65 \mathrm{~g} \mathrm{~cm}^{-3}[55]$.

\subsection{Statistical analysis}

Data were first checked for normality. Those data which were not normally distributed were log transformed. All variables were subjected to paired samples $t$ test statistics

\section{SN Applied Sciences}


at $5 \%$ level of significance using SPSS version 20 to compare the land uses. The mean of the analyzed soil properties of the 18 plots from the exclosure were compared to the mean of the 18 plots in grazing land. Pearson correlation test was also used to analyze the relationship among the different soil properties.

\section{Results and discussions}

Significantly $(p<0.001)$ higher SOC was measured in the exclosure $(1.89 \pm 0.1 \mathrm{~g} / 100 \mathrm{~g})$ as compared to the grazing land $(1.29 \pm 0.06 \mathrm{~g} / 100 \mathrm{~g})$ (Table 3). Likewise, conversion of the grazing land to exclosure had brought significant $(p<0.001)$ variation in SOC stock. It has improved from $45.64 \pm 2.57 \mathrm{Mg} \mathrm{ha}^{-1}$ in the grazing land to $73.61 \pm 4.94 \mathrm{Mg} \mathrm{ha}^{-1}$ in the exclosure (Fig. 4), showing an increase by $61.3 \%$ and indicates the land use conversion has added an average of $1.65 \mathrm{Mg} \mathrm{ha}^{-1}$ of SOC stock per annum. The reasons for lower SOC and SOC stock in the grazing land might be due to loss of soil structure by livestock free grazing and removal of vegetation by both livestock and human, which might have exposed soil materials to erosion [56], whereas higher amount of organic carbon in the exclosure might be due to higher leaf litter, reduced soil erosion as a result of higher vegetation cover as well as low agitation in the soils of the exclosure. This corresponds with the findings of Gebremariam and Kebede [57] in Tahtay Adiabo district, Northern Ethiopia, who reported an enhancement of SOC stock by $25 \%$; Gebreanenia [24] an increase of SOC by $80 \%$ in Alamata district, Southern Tigray. Authors $[7,8,11,20]$ also reported from different districts of Tigray region that conversion of grazing lands to exclosures improved SOC stock and SOC significantly. Similarly, Yimer et al. [21] from Dodota sire district, Ethiopia, pointed out that an exclosure enhanced SOC by $13.5 \%$ compared to grazing land.

The conversion of open grazing land to an exclosure has significantly $(p<0.05)$ improved the TN level from $0.11 \pm 0.01 \mathrm{~g} / 100 \mathrm{~g}$ in the grazing land to $0.16 \pm 0.02 \mathrm{~g} / 100 \mathrm{~g}$ in the exclosure (Table 3 ). This result indicated that conversion of the grazing land to exclosure

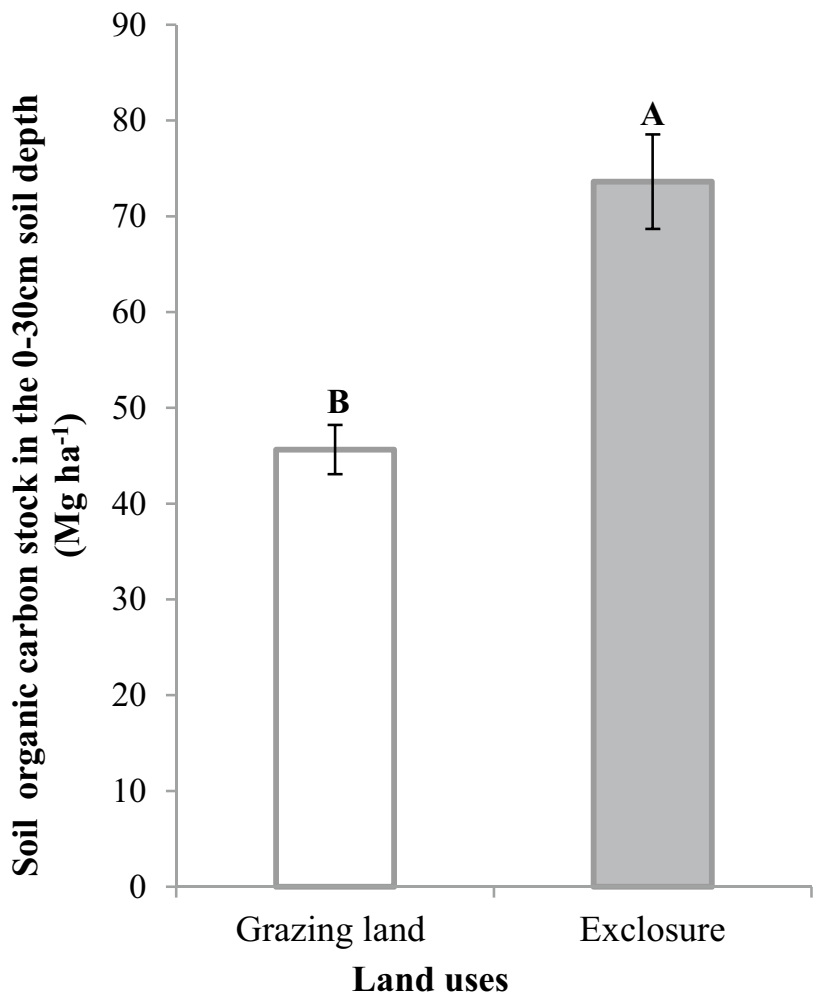

Fig. 4 Effect of conversion of open grazing land to exclosure on SOC stock $\left(\mathrm{Mg} \mathrm{ha}^{-1}\right)$. Different letters represent significant difference between the land uses. Error bars denote standard error

converted the low level of nitrogen to optimum level. According to ATA [58], TN is low if is $0.1-0.15 \%$ and optimum if it is $0.15-3.0 \%$. This could be due to higher soil organic matter content and the presence of nitrogen fixing plants in the exclosure compared to the grazing land. Pearson correlation matrix (Table 4) also showed that TN was positively and significantly associated with SOC $(r=0.746, p<0.01)$. According to Niknahad et al. [59], soil organic matter is the most important source of TN; hence, changes in soil TN are likely related to organic matter change in rangelands. This confirms the finding of Gebreanenia [24], who reported an enhancement by more than twofold in Southern Tigray and Mureithi et al. [60] by $83 \%$

Table 3 Comparison of soil chemical properties between exclosure and grazing land at 0-30 cm depth (Mean \pm SEM)

\begin{tabular}{|c|c|c|c|c|c|c|c|}
\hline \multirow[t]{2}{*}{ LUT } & \multicolumn{7}{|c|}{ Soil parameters } \\
\hline & Soil pH & $\mathrm{EC}\left(\mathrm{ds} \mathrm{m^{-1 } )}\right.$ & $\mathrm{CEC}\left(\mathrm{cmol}(+) \mathrm{kg}^{-1}\right)$ & TN (g/100 g) & $\operatorname{avP}\left(\mathrm{mg} \mathrm{kg}^{-1}\right)$ & $\operatorname{avK}\left(\mathrm{mg} \mathrm{kg}^{-1}\right)$ & $\operatorname{SOC}(\mathrm{g} / 100 \mathrm{~g})$ \\
\hline $\operatorname{EX}(n=18)$ & $6.74 \pm 0.03^{\mathrm{a}}$ & $0.14 \pm 0.01^{\mathrm{a}}$ & $35.53 \pm 1.06^{a}$ & $0.16 \pm 0.02^{\mathrm{a}}$ & $5.18 \pm 0.25^{\mathrm{a}}$ & $63.27 \pm 0.54^{\mathrm{a}}$ & $1.89 \pm 0.11^{\mathrm{a}}$ \\
\hline $\mathrm{GL}(n=18)$ & $6.82 \pm 0.04^{\mathrm{a}}$ & $0.16 \pm 0.01^{\mathrm{a}}$ & $30.41 \pm 1.39^{b}$ & $0.11 \pm 0.01^{b}$ & $4.52 \pm 0.32^{\mathrm{a}}$ & $47.21 \pm 0.46^{b}$ & $1.29 \pm 0.06^{b}$ \\
\hline$p$ values & 0.191 & 0.167 & 0.003 & 0.023 & 0.082 & 0.000 & 0.000 \\
\hline
\end{tabular}

Means with the same superscript letters are not significantly different at $p<0.05$

LUT Land use type, EX Exclosure, GL Grazing land, $n$ represents number of plots 
Table 4 Pearson correlation matrix among different soil properties

\begin{tabular}{lcllllll}
\hline & Soil pH & EC & avP & TN & avK & CEC & SOC \\
\hline Soil pH & 1.00 & & & & & & \\
EC & -0.230 & 1.00 & & & & & \\
avP & 0.145 & -0.271 & 1.00 & & & & \\
TN & 0.372 & -0.380 & 0.400 & 1.00 & & & \\
avK & 0.454 & $-0.501^{*}$ & 0.322 & $0.900^{* *}$ & 1.00 & & \\
CEC & 0.223 & -0.107 & 0.369 & $0.711^{* *}$ & $0.731^{* *}$ & 1.00 & \\
SOC & 0.329 & -368 & 0.362 & $0.746^{* *}$ & $0.763^{* *}$ & $0.837^{* *}$ & 1.00 \\
\hline
\end{tabular}

EC Electrical conductivity, avP available phosphorus, $T N$ total nitrogen, avK available potassium, CEC cation exchange capacity, SOC soil organic carbon

*Correlation is significant at the 0.05 level

${ }^{* *}$ Correlation is significant at the 0.01 level in semi-arid range land of Kenya. Other prior studies [6, 23], also indicated a positive impact of exclosures on soil nitrogen content. Nonetheless, it contradicts a report by Munie [16], from South Western Ethiopia, who pointed out that TN in the soil decreased by $50 \%$ after conversion of grazing land into exclosure and Yong-Zhong et al. [61] and Yimer et al. [21], who reported that exclosures and grazing lands were not significantly different in TN \% level. The difference from this study could be due to difference in rate of decomposition of soil organic matter as a result of difference in temperature, rainfall and soil $\mathrm{pH}$. For instance, Munie ([16] conducted the study in Illubabor zone, South Western Ethiopia, at an elevation of 1800 m.a.s.l, with a minimum and maximum annual temperature of 12.7 and $25.6^{\circ} \mathrm{C}$ which is lower than in this study. Besides, the study area was more acidic (4.3-6.7) than in this study. Yimer et al. [21], from Dodota Sire, Arsi zone (with an elevation of 1635-1795 m.a.s.sl and annual rainfall of 500-700 mm), also reported a non-significant difference between the two land uses. According to Pineiro et al. [62], a difference in temperature could bring a difference in rate of decomposition of soil organic matter and in turn the level of TN. Soil acidity can also adversely affect the nitrogen level as well. A study conducted in Mongolia, Northern China, has also shown that the land use conversion didn't affect the TN level significantly [61]. The study area, Mongolia, has different and lowest mean temperature $\left(6.5^{\circ} \mathrm{C}\right)$ and rainfall $(366 \mathrm{~mm})$ than the area in this study.

The result demonstrated that conversion of open grazing lands to an exclosure had no significant $((p>0.05)$ effect on the level of avP. However, the mean value was slightly higher in the exclosure than in the open grazing land. The numerical, but not statistical difference in phosphorus level between the land uses could be due to addition of animal manure to the grazing land which in turn could slightly increase the avP level since interference of animals is allowed in the grazing land. According to Munie [16], faeces of animals could enhance the level of soil nutrients in grazing lands. Generally, the avP in the study area is classified as acutely deficient, indicating that there is high deficiency of avP in the study area. According to ATA [58], majority of Tigray region soils, including the study district, were categorized under 'very low' (0-15 mg g-1) status. The present study is in agreement with the findings of Asmamaw [28]; Lu et al. [63] and Umer and Sinore [64], who did not report a significant difference between the land uses in their avP level. In contrast to these findings, Bahiru [25] and Mekuria [26] reported that the conversion of open grazing lands into exclosures enhanced the level of avP and Legesse [27] found a higher value of avP in communal grazing land compared with 22 years old exclosure. In addition, Ajorlo et al. [65], from Malaysia reported significantly higher AvP in grazed areas than exclosures. According to Prasad and Power [66], the presence of phosphorus content depends upon a number of factors such as vegetation type, soil texture, climate and drainage. This might bring a difference between the result in this study and other various prior studies.

Available potassium in the exclosure ranged from 59.6 to $67.2 \mathrm{mg} \mathrm{kg}^{-1}$, with a mean value of $63.27 \pm 0.54 \mathrm{mg} \mathrm{kg}^{-1}$, while it ranges from 43.4 to 50.5 , with a mean value of $\left.47.21 \pm 0.46 \mathrm{mg} \mathrm{kg}^{-1}\right)$ in the grazing land and it was significantly $(p<0.001)$ higher in the exclosure than the grazing land (Table 3). The lower available potassium content of the grazing land could be due to higher soil leaching rates. According to Hosseinzadeh et al. [67], grazing can cause higher soil leaching rates and in turn lower potassium content since it is cashed more easily than other nutrients. Moraes and Dynia [68] considered $\mathrm{K}$ as the most easily leached cation due to its displacement to the soil solution and to its percolation. Legesse [27], also pointed out that because of its high mobility in the soil, avK is most susceptible to leaching losses, which might be the reason for the decline of this vital nutrient in free grazing land. The finding in this study corroborates with prior studies at different districts in Ethiopia [11, 27, 29]. 
The process of conversion of open grazing land to exclosure has improved the CEC level significantly $(p<0.05)$. The mean value has increased from $30.41 \pm 1.39 \mathrm{cmol}(+) / \mathrm{kg})$ in the grazing land to $35.53 \pm 1.06 \mathrm{cmol}(+) / \mathrm{kg})$ in the exclosure (Table 3 ), indicating an enhancement of $16.8 \%$. The difference in CEC level between the land use types may be attributed to the higher soil organic matter content in the exclosure. According to Moges et al. [69], the level of CEC of soils depends mainly on the amount of soil organic matter available in the soil. This is also supported by correlation matrix (Table 4) that showed positive and significant association of CEC with SOC $(r=0.837, p<0.01)$, reflecting that the increase in soil organic matter could increase the CEC level. The present study supports the findings of different authors [16, 30,64], who reported higher CEC in exclosures of different ages than their adjacent open grazing areas. However, it is not consistent with a finding by Abiyu et al. [31] and Oduor et al. [70] at South Wello Zone, Ethiopia and Northwestern Kenya, respectively, who found that exclosures and grazing lands didn't vary significantly in their CEC level and Mekuria et al. [22], who pointed out that grazing lands showed higher CEC level than 7 year old exclosure. Such variation in the changes in soil CEC level across different study sites might be due to difference in the rainfall and temperature which determines the rate of decomposition of soil organic matter [62].

Though not significant $(p>0.05)$, the grazing land had slightly higher EC level $\left(0.16 \pm 0.01 \mathrm{ds}^{-1}\right)$ than the exclosure $\left(0.14 \pm 0.01 \mathrm{ds} \mathrm{m}^{-1}\right.$ ) (Table 3 ). The insignificant higher soil salinity in the grazing land could be due to the absence of foliage vegetation cover which leads to relatively higher evaporation and poor infiltration. This result comes to an agreement with a finding by Gebreanenia [24], who indicated that conversion of open grazing land to an exclosure decreased the EC level by $10 \%$, but the difference was not statistically significant. Similar results were also reported from previous studies [29, 64]. However, the present finding was not consistent with a finding by Munie [16], who reported that EC was significantly higher in exclosure than grazing land.

The conversion of the land uses didn't bring significant $(p>0.05)$ change in soil pH level (Table 3 ), though the grazing land had numerically higher soil $\mathrm{pH}$ than exclosure. The numerically but not statistically lower soil $\mathrm{pH}$ in the exclosure could be due to more root biomass and active microorganism metabolism in the rhizosphere, which helps to reduce $\mathrm{pH}$ level as a result of extensive secretion of organic acids from roots and amount of $\mathrm{CO}_{2}$ released from roots and microorganisms [61,71, 72]. This result is in-line with the result found by Mureithi et al. [60], who reported that conversion of grazing lands into exclosures didn't affect soil pH significantly, but was not consistent with a study by Mekuria et al. [22], who found that exclosures of age 4-7 years had significantly higher soil $\mathrm{pH}$ than communal grazing lands and 2-year old exclosure. Umer and Sinore [64] also reported a significantly higher soil $\mathrm{pH}$ in an exclosure than the grazing land in southern Ethiopia after six years of exclusion.

\section{Conclusions}

The conversion of open grazing land to an exclosure improved most of the soil properties except soil pH, EC and avP. The land use conversion enhanced SOC stock and soil properties like SOC, TN, av. K and CEC significantly. From the result, it can be concluded that establishment of exclosures on degraded communal grazing lands is a viable option to enhance degraded soils. As the present study focused only on soil chemical properties and soil organic carbon stock, further studies on fauna and microorganisms, erosion control, hydrology, downstream agricultural production and socio-economic factors analysis that determine the sustainability of the land use systems need to be undertaken.

Acknowledgements The authors are grateful to the Ecological Organic Agriculture (EOA) Project for financial support. We also express sincere thanks to the village extension agents and administrators and inhabitants of the study area for providing information.

Authors' contributions KA, ST and KT designed the study. KA collected the soil samples and conducted the laboratory experiment. KA and ST analyzed the data. KA, ST and KT wrote the manuscript. All authors read and approved the final manuscript.

Funding Ecological Organic Agriculture (EOA) project funded the research work.

Availability of data and materials Upon request, the data and materials used in this article are available from the corresponding author.

\section{Compliance with ethical standards}

Conflict of interest The authors declared that they have no conflict of interest.

\section{References}

1. Haile G, Lemenhi M, Itanna F, Senbeta F (2014) Impacts of land uses changes on soil fertility, carbon and nitrogen stock under small holder farmers in Central highlands of Ethiopia: implication for sustainable agricultural land scape management around Butajira Area. N Y Sci J 7(2):27-44

2. Yitbarek TW, Belliethathan S, Stringer LC (2012) The onsite cost of gully erosion and cost-benefit of gully rehabilitation: a case study in Ethiopia. Land Degrad Dev 23(2):157-166. https://doi. org/10.1002/ldr.1065 
3. FAO (2010) Global forest resources assessment-country report Ethiopia. Food and Agriculture Organization (FAO), Rome

4. Tadesse D (2014) Impacts and impediments of community participation on soil and water conservation to sustainable land resource management in LaelayMaychew Woreda, Tigray, Ethiopia. M.Sc.thesis. Addis Ababa University. Addis Ababa, Ethiopia

5. Nedessa B, Ali J, Nyborg I (2005) Exploring ecological and socioeconomic issues for the improvement of area enclosure management. A case study from Ethiopia. Dry lands Coordination Group, report no. 38.1-55

6. Mekuria W, Aynekulu E (2011) Exclosure land management for restoration of the soils in degraded communal grazing lands in northern Ethiopia. Land Degrad Dev. https://doi.org/10.1002/ Idr.1146

7. Mekuria W, Veldkamp E, Corre MD, Haile M (2011) Restoration of ecosystem carbon stocks following exclosure establishment in communal grazing lands in Tigray. Ethiopia. Soil Sci Soc Am J 75(1):246-256. https://doi.org/10.2136/sssaj2010.0176

8. Hishe S, Lyimo J, Bewket W (2017) Soil and water conservation effects on soil properties in the Middle Silluh Valley, northern Ethiopia. Int Soil Water Conserv Res 5(3):231-240. https://doi. org/10.1016/j.iswcr.2017.06.005

9. Gebremedihin KM, Birhane E, Tadesse T, Gbrewahid H (2018) Restoration of degraded drylands through exclosures enhancing woody species diversity and soil nutrients in the highlands of Tigray, Northern Ethiopia. Nat Conserv Res 3(1):1-20. https:// doi.org/10.24189/ncr.2018.001

10. Welemariam M, Kebede F, Bedadi B, Birhane E (2018) Exclosures backed up with community-based soil and water conservation practices increased soil organic carbon stock and microbial biomass carbon distribution, in the northern highlands of Ethiopia. Chem Biol Technol Agric 5(1):12. https://doi.org/10.1186/s4053 8-018-0124-1

11. Welemariam M, Kebede F, Bedadi B, Birhane E (2018) Effect of community-based soil and water conservation practices on soil glomalin, aggregate size distribution, aggregate stability and aggregate-associated organic carbon in northern highlands of Ethiopia. Agric Food Secur 7(1):42. https://doi.org/10.1186/ s40066-018-0193-1

12. Manaye A, Negash M, Alebachew M (2019) Effect of degraded land rehabilitation on carbon stocks and biodiversity in semiarid region of Northern Ethiopia. For Sci Technol 15(2):70-79. https://doi.org/10.1080/21580103.2019.1592787

13. Amiri F, Ariapor A, Fadai S (2008) Effects of livestock grazing on vegetation composition and soil moisture properties in grazed and non-grazed range site. J Biol Sci 8(8):1289-1297

14. Evans CRW, Krzic M, Broersma K, Thompson DJ (2012) Long-term grazing effects on grassland soil properties in southern British Columbia. Can J Soil Sci 92(4):685-693

15. Chaneton EJ, Lavado RS (1996) Soil nutrients and salinity after long-term grazing exclusion in a Flooding Pampa grassland. J Range Manag 49:182-187

16. Munie SA (2013) Effect of plantation forests on soil chemical properties, soil temperature and regeneration of woody plants: a comparative analysis. Ph.D. dissertation. Mendel University in Brno, Czech Republic, pp 1-111

17. Marland G, Garten CT, Post WM, West TO (2004) Studies on enhancing carbon sequestration in soils. Energy 29(9):16431650. https://doi.org/10.1016/j.energy.2004.03.066

18. Conant RT, Ogle SM, Paul EA, Paustian K (2011) Measuring and monitoring soil organic carbon stocks in agricultural lands for climate mitigation. Front Ecol Environ 9(3):169-173. https://doi. org/10.1890/090153

19. Mekuria W, Langan S, Noble A, Johnston R (2017) Soil restoration after seven years of exclosure management in northwestern
Ethiopia. Land Degrad Dev 28(4):1287-1297. https://doi. org/10.1002/ldr.2527

20. Mekuria W, Veldkamp E, Haile M (2009) Carbon stock changes with relation to land use conversion in the low lands of Tigray, Ethiopia. In: Conference on international research on food security, natural resource management and rural development. University of Hamburg, Germany. Retrieved from http://www.trope ntag.de/2009/abstracts/full/184.pdf. Accessed 8 Jan 2020

21. Yimer F, Alemu G, Abdelkadir A (2015) Soil property variations in relation to exclosure and open grazing land use types in the Central Rift Valley area of Ethiopia. Environ Syst Res 4(1):17. https ://doi.org/10.1186/s40068-015-0041-2

22. Mekuria W, Langan S, Noble A, Johnston R (2014) Soil organic carbon and nutrient contents are not influenced by exclosures established in communal grazing land in Nile basin, Northern Ethiopia. In: International conference on advances in agricultural, biological \& environmental sciences (AABES-2014) October, pp 15-16. Retrieved from https://iicbe.org/upload/5899C 1014045.pdf. Accessed 28 Jan 2020

23. Tiki L, Tadesse M, Yimer F (2015) Effects of integrating different soil and water conservation measures into hillside area closure on selected soil properties in Hawassa Zuria District, Ethiopia. J Soil Sci Environ Manag 6(10):268-274

24. Gebreanenia G (2018) The role of area enclosure on the rehabilitation of woody species composition and its socio-economic importance in Gratkahssu Forest of Southern Tigray. M.sc. thesis, Addis Ababa University. Retrieved from http://213.55.95.56/bitst ream/handle/123456789/18316/Gebremedhin\%20Gebreane nia\%20\%20\%202018.pdf?sequence=1\&isAllowed=y. Accessed 6 Jan 2020

25. Bahiru K M (2008) Enclosure as a viable option for rehabilitation of degraded lands and biodiversity conservation: the case of Kallu Woreda, Southern Wello. Addis Ababa University School of Graduate Studies, Ethiopia, pp 1-99. Retrieved from https:// pdfs.semanticscholar.org/3be0/257180cd04daf0d07bfbac2d4 c942f1830f2.pdf

26. Mekuria W (2013) Changes in regulating ecosystem services following establishing exclosures on communal grazing lands in Ethiopia: a synthesis. J Ecosyst. https://doi. org/10.1155/2013/860736

27. Legesse AT (2008) Area closure as a strategy for land management: a case study at Kelala Dalacha enclosure in the central rift valley of Ethiopia. M.Sc. thesis, Addis Ababa University, Ethiopia. Retrieved from http://etd.aau.edu.et/bitstream/handle/12345 6789/3910/Abiy\%20Tsetargachew.pdf?sequence=1\&is All owed=y. Accessed 12 Jan 2020

28. Asmamaw MM (2011) The role of area closures for soil and Woody Vegetation Rehabilitation in Kewot District, North Shewa. M.Sc. Thesis. Addis Ababa University, Ethiopia, pp 1-93. Retrieved from http://etd.aau.edu.et/bitstream/handle/12345 6789/6574/Mengistu\%20Asmamaw.pdf?sequence=1\&isAll owed $=y$. Accessed 10 Feb 2020

29. Tadesse AY (2011) The impact of area enclosure on soil quality and farmers perception: the case of Tachignaw Gimbichu enclosure in Shashogo woreda, Southern Ethiopia. M.Sc. thesis. Addis Ababa University, Addis Ababa. Ethiopia. Retrieved from http://213.55.95.56/bitstream/handle/123456789/3862/Abine t\%20Tadesse.pdf? sequence $=1$ \&isAllowed=y. Accessed 15 Jan 2020

30. Mekuria W, Wondie M, Amare T, Wubet A, Feyisa T, Yitaferu B (2018) Restoration of degraded landscapes for ecosystem services in North-Western Ethiopia. Heliyon 4(8):e00764. https:// doi.org/10.1016/j.heliyon.2018.e00764

31. Abiyu A, Lemenih M, Gratzer G, Aerts R, Teketay D, Glatzel $G$ (2011) Status of native woody species diversity and soil 
characteristics in an exclosure and in plantations of Eucalyptus globulus and Cupressus lusitanica in Northern Ethiopia. Mt Res Dev 31(2):144-152. https://doi.org/10.1659/MRD-JOURNAL-D10-00116.1

32. McSherry ME, Ritchie ME (2013) Effects of grazing on grassland soil carbon: a global review. Glob Change Biol 19:1347-1357

33. Wang C, Han X, Xing X (2010) Effects of grazing exclusion on soil net nitrogen mineralization and nitrogen availability in a temperate steppe in northern China. J Arid Environ 74(10):1287-1293

34. Luan J, Cui L, Xiang C, Wu J, Song H, Ma Q, Hu Z (2014) Different grazing removal exclosures effects on soil $\mathrm{C}$ stocks among alpine ecosystems in east Qinghai-Tibet Plateau. Ecol Eng 64:262-268

35. Darcha G, Abay K, Birhane N (2018) Evaluation of Awir (Ipomoea carnea) for Gully Rehabilitation through different propagation techniques in North Western Zone of Tigray. J Agric Ecol Res Int. https://doi.org/10.9734/JAERI/2018/39723

36. Hurni H, Berhe WA, Chadhokar P, Daniel D, Gete Z, Grunder M, Kassaye G (2016) Soil and water conservation in ethiopia: guidelines for development agents. Second revised edition. Bern, Switzerland: Centre for Development and Environment (CDE), University of Bern, with Bern Open Publishing (BOP). 134 pp. https://boris.unibe.ch/80013/1/Guidelines_Soil_and_Water Conservation_in_Ethiopia_2016.pdf

37. FAO (1998) Land and Water Digital Media series: the soil and terrain data base for north eastern Africa. FAO (land and water digital media series no. 2). FAO, Rome

38. FAO (Food and Agriculture Organization of the United Nations) (2006). World reference base for soil resources

39. Fukami T, Wardle DA (2005) Long-term ecological dynamics: reciprocal insights from natural and anthropogenic gradients. Proc R Soc B Biol Sci 272(1577):2105-2115

40. Pickett ST (1989) Space-for-time substitution as an alternative to long-term studies. In: Long-term studies in ecology. Springer, New York, pp 110-135

41. Fang W, Peng SL (1997) Development of species diversity in the restoration process of establishing a tropical man-made forest ecosystem in China. For Ecol Manag 99(1-2):185-196

42. Li XR, Kong DS, Tan HJ, Wang XP (2007) Changes in soil and vegetation following stabilisation of dunes in the southeastern fringe of the Tengger Desert, China. Plant Soil 300(1-2):221-231

43. Sparling GP, Schipper LA, Bettjeman W, Hill R (2004) Soil quality monitoring in New Zealand: practical lessons from a 6-year trial. Agr Ecosyst Environ 104(3):523-534

44. Mekuria W, Yami M (2013) Changes in woody species composition following establishing exclosures on grazing lands in the lowlands of Northern Ethiopia. Afr J Environ Sci Technol 7(1):3040. https://doi.org/10.5897/AJEST11.378

45. Food and Agriculture Organization of the United Nations (FAO) (2019) Measuring and modelling soil carbon stocks and stock changes in livestock production systems-Guidelines for assessment (Draft for public review). Livestock Environmental Assessment and Performance (LEAP) Partnership. FAO, Rome, Italy. Retrieved from http://www.fao.org/3/CA2934EN/ca2934en. pdf. Accessed 18 Jan 2020

46. Badgery WB, Simmons AT, Murphy BW, Rawson A, Andersson KO, Lonergan VE (2014) The influence of land use and management on soil carbon levels for crop-pasture systems in Central New South Wales, Australia. Agr Ecosyst Environ 196:147-157. https ://doi.org/10.1016/j.agee.2014.06.026

47. Jackson M (1958) Soil chemical analysis, 6th edn. Englewood Cliffs, Prentice Halls Inc., p 498

48. Olsen SR, Sommers LE (1982) Phosphorus. In: Page AL, Miller LH, Keeney DR (eds) Methods of soil analysis. Part 2. Chemical and microbiological properties. Agronomy monograph, vol 9. American Society of Agronomy, Madison, pp 403-430

49. Walkley A, Black IA (1934) Chromic acid titration for determination of soil organic matter. Soil Sci 63:239-251

50. Mclean EO (1982) Soil pH and lime requirement. Methods of soil analysis. Chemical and microbiological properties. Agronomy monograph, seconded, vol 9. American Society of Agronomy, Madison, pp 199-224

51. Black CA (1965) Methods of soil analysis: physical and mineralogical properties, including statistics of measurement and sampling. Part 2. Chemical and microbiological properties. Agronomy 9:1387-1388

52. Van Reeuwijk LP (1992) Procedures for soil analysis, 3rd edn. International Soil Reference Centre Wageningen (ISRIC), Wageningen

53. Houba V, Vander L, Novazamsky I, Walinga I (1989) Plant and soil analysis procedures. Department of Soil Science and Plant Nutrition Agriculture University, Wageningen

54. Grossman RB, Reinsch TG (2002) Bulk density and linear extensibility. Methods Soil Anal 4 Phys Methods 5:201-228

55. Pradhan BM, Awasthi KD, Bajracharya RM (2012) Soil organic carbon stocks under different forest types in Pokhare Khola sub-watershed: a case study from Dhading district of Nepal. WIT Trans Ecol Environ 157:535-546. https://doi.org/10.2495/ AIR120471

56. Itanna F, Olsson M, Stahr K (2011) Effect of land use changes on soil carbon status of some soil types in the Ethiopian Rift valley. J Dry Lands 4(1):289-299

57. Gebremariam M, Kebede F (2010) Land use change effect on soil carbon stock, above ground biomass, aggregate stability and soil crust: a case from Tahtay Adyabo, North Western Tigray, Northern Ethiopia. J Dry Lands 3(2):220-225

58. ATA (Agricultural Transformation Agency) (2014) Soil fertility status and fertilizer recommendation Atlas for Tigray Regional State, Ethiopia. Retrieved from http://www.ata.gov.et/downl oad/soil-fertility-status-fertilizer-recommendation-atlas-tigra y-regional-state_jul2014/. Accessed 21 Feb 2020

59. Niknahad G, Sheidai-Karkaj E, Jafari I (2016) Effects of exclosure on soil properties in winter rangelands in Golestan Province, Iran. J Rangel Sci 7(1):55-66

60. Mureithi SM, Verdoodt A, Gachene CK, Njoka JT, Wasonga VO, De Neve S, Van Ranst E (2014) Impact of enclosure management on soil properties and microbial biomass in a restored semiarid rangeland, Kenya. J Arid Land 6(5):561-570. https://doi. org/10.1007/s40333-014-0065-x

61. Yong-Zhong S, Yu-Lin L, Jian-Yuan C, Wen-Zhi Z (2005) Influences of continuous grazing and livestock exclusion on soil properties in a degraded sandy grassland, Inner Mongolia, northern China. CATENA 59(3):267-278. https://doi.org/10.1016/j.caten a.2004.09.001

62. Pineiro G, Paruelo JM, Oesterheld M, Jobbágy EG (2010) An assessment of grazing effects on soil carbon stocks in grasslands. Rangel Ecol Manag. https://doi.org/10.2111/08-255.1

63. Lu X, Yan Y, Sun J, Zhang X, Chen Y, Wang X, Cheng G (2015) Short-term grazing exclusion has no impact on soil properties and nutrients of degraded alpine grassland in Tibet. China. Solid Earth 6(4):1195-1205. https://doi.org/10.5194/se-6-1195-2015

64. Umer S, Sinore T (2019) Effects of area exclosure on soil properties and farmers' awareness towards the practice in Wera SubWatershed at Analemo Woreda, Southern Ethiopia. Int J Agric Environ Sci 4(1):1-7

65. Ajorlo M, Abdullah R, Hanif AH, Halim RA, Yusoff MK (2011) Impacts of livestock grazing on selected soil chemical properties in intensively managed pastures of Peninsular Malaysia. J Trop Agric Sci 34(1):109-121 
66. Prasad R, Power JF (1997) Soil fertility management for sustainable agriculture. Lewis Publishers in an Imprint of CRC Press, 243. Retrieved from https://www.scirp.org/(S(czeh2tfqyw2orz5 53k1w0r45))/reference/ReferencesPapers.aspx?Referencel $\mathrm{D}=1818339$. Accessed 22 Dec 2019

67. Hosseinzadeh G, Jalilvand H, Tamartash R (2010) Short time impact of enclosure on vegetation cover, productivity and some physical and chemical soil properties. J Appl Sci 10(18):2001-2009

68. Moraes JFV, Dynia JF (1992) Modifications in chemical and physico-chemical characteristics of low humic gley soil under flooding and after drainage. Pesquisa Agropecuaria Brasileira (Brazil)

69. Moges A, Dagnachew M, Yimer F (2013) Land use effects on soil quality indicators: a case study of Abo-Wonsho, Southern Ethiopia. Appl. Environ. Soil Sci. https://doi.org/10.1155/2013/78498 9
70. Oduor CO, Karanja NK, Onwonga RN, Mureithi SM, Pelster D, Nyberg G (2018) Enhancing soil organic carbon, particulate organic carbon and microbial biomass in semi-arid rangeland using pasture enclosures. BMC Ecol 18(1):45. https://doi. org/10.1186/s12898-018-0202-z

71. Hinsinger P, Plassard C, Tang C, Jaillard B (2003) Origins of rootmediated $\mathrm{pH}$ changes in the rhizosphere and their responses to environmental constraints: a review. Plant Soil 248(12):43-59

72. Jones DL, Hodge A, Kuzyakov Y (2004) Plant and mycorrhizal regulation of rhizodeposition. New Phytol 163(3):459-480. https ://doi.org/10.1111/j.1469-8137.2004.01130.x

Publisher's Note Springer Nature remains neutral with regard to jurisdictional claims in published maps and institutional affiliations. 